\title{
Solubilized Myocardial Adenylate Cyclase
}

\author{
RESTORATION OF HISTAMINE RESPONSIVENESS \\ BY PHOSPHATIDYLSERINE
}

\author{
Gerald S. Levey and Irwin Kuein \\ From the Division of Endocrinology and Metabolism, Department of Medicine, \\ University of Miami School of Medicine, Miami, Florida 33152
}

A B S TRACT We have recently described the preparation of a solubilized cat myocardial adenylate cyclase which is unresponsive to histamine, norepinephrine, glucagon, and thyroxine, the hormones which activate the particulate enzyme. Since hormone receptors may consist of proteins and phospholipids, we determined the effect of several phospholipids on restoring the responsiveness of the solubilized adenylate cyclase to histamine. The addition of phosphatidylserine completely restored the histamine-mediated activation of the solubilized enzyme in contrast to phosphatidylethanolamine and phosphatidylinositol which were without effect. The concentration of histamine producing halfmaximal activation of adenylate cyclase, $2 \times 10^{-5} \mathrm{M}$, was virtually identical with that observed in the particulate preparation. The antihistamine, diphenhydramine, $8 \times 10^{-5} \mathrm{M}$, abolished activation of adenylate cyclase by histamine in both the solubilized and particulate preparations. Phosphatidylserine also restored glucagon responsiveness, but did not restore norepinephrine responsivness. It would appear that phosphatidylserine produced the necessary molecular configuration of the adenylate cyclase for histamine binding and activation of the enzyme.

\section{INTRODUCTION}

Histamine has been shown to exert positive inotropic and chronotropic effects, independent of the adrenergic nervous system, on isolated heart preparations (1-3). In addition, histamine activates adenylate cyclase in particulate preparations of guinea pig, cat, and human

Dr. Levey is an Investigator of the Howard Hughes Medical Institute. Mr. Klein is a third-year medical student at New York University School of Medicine.

Received for publication 16 November 1971 and in revised form 12 January 1972. heart (4). We have recently described the preparation of a solubilized cat myocardial adenylate cyclase using a nonionic detergent, Lubrol-PX, an ethylene oxide condensate of dodecanol $(5,6)$. The enzyme in the presence of detergent or freed of detergent by diethylaminoethyl (DEAE)-cellulose chromatography was unresponsive to the hormones activating the particulate (membrane-bound) adenylate cyclase including histamine (4), the catecholamines ( 7$)$, glucagon (8), and thyroxine and triiodothyronine (9). Current evidence strongly indicates the probability that hormone receptors consist of proteins and phospholipids $(10,11)$. In this regard, we have recently reported in a preliminary communication that the addition of pure phosphatidylserine restored glucagon responsiveness to the solubilized myocardial adenylate cyclase (12).

This investigation demonstrates that phosphatidylserine also restores histamine responsiveness to the solubilized adenylate cyclase. In addition, the activation is abolished by the antihistamine, diphenhydramine.

\section{METHODS}

Preparation of detergent-free, solubilized adenylate cyclase. Normal cats were anesthetized with pentobarbital, 25-35 $\mathrm{mg} / \mathrm{kg}$ intraperitoneally, and the heart was quickly excised. The left ventricle was dissected free of endocardium and epicardium and about $300 \mathrm{mg}$ of muscle was homogenized with a motor-driven homogenizer in $4.5 \mathrm{ml}$ of cold solution containing, in final concentration sucrose, $0.25 \mathrm{M}$; Tris- $\mathrm{HCl}$, $10 \mathrm{~mm}$; $\mathrm{pH} 7.7$; Lubrol-PX, $20 \mathrm{~mm}$; ethylenediaminetetraacetate (EDTA) and -magnesium chloride, $1 \mathrm{~mm}$. The homogenate was centrifuged at $12,000 \mathrm{~g}$ for $10 \mathrm{~min}$ at $4^{\circ} \mathrm{C}$. Approximately $1.3 \mathrm{ml}$ of the $12,000 \mathrm{~g}$ supernatant containing the solubilized myocardial adenylate cyclase and having a protein concentration of $4 \mathrm{mg} / \mathrm{ml}$ was applied to a 1.0 $\times 12.0 \mathrm{~cm}$ DEAE-cellulose column equilibrated at $4^{\circ} \mathrm{C}$ in Tris- $\mathrm{HCl}, 10 \mathrm{~mm}, \mathrm{pH}$ 7.7. The flow rate was approximately $0.20 \mathrm{ml} / \mathrm{min}$. The column containing the enzyme was washed with 15-20 volumes of Tris- $\mathrm{HCl}, 10 \mathrm{~mm}, \mathrm{pH} \mathrm{7.7.} \mathrm{Adenylate}$ cyclase was eluted with Tris- $\mathrm{HCl}, 1 \mathrm{M}, \mathrm{pH}$ 7.7. The frac- 
tion containing adenylate cyclase activity has been shown to be totally free of detergent using Lubrol-PX labeled with ${ }^{14} \mathrm{C}$ in the ethylene oxide moiety (6).

Preparation of phosphatidylserine. Phosphatidylserine was obtained as a $25 \mathrm{mg} / \mathrm{ml}$ solution in $\mathrm{CHCl}_{3}$. Approximately $0.17 \mathrm{ml}$ was placed in a $10 \times 75 \mathrm{~mm}$ glass test tube and the $\mathrm{CHCl}_{3}$ was removed by evaporation with a stream of nitrogen. $1 \mathrm{ml}$ of Tris- $\mathrm{HCl}, 10 \mathrm{~mm}, \mathrm{pH} \mathrm{7.7,} \mathrm{was} \mathrm{added}$ to the residue and the lipid was dispersed by sonication with a Sonifier Cell Disrupter, Model W185 (Branson Sonic Power Co., Danbury, Conn.), until there was no apparent change in clarity of the solution, generally $\frac{1}{2}-1 \mathrm{~min}$. The phosphatidylserine yielded one spot with thin-layer chromatography in either of two separate solvent systems, either $\mathrm{CHCl}_{3}: \mathrm{CH}_{3} \mathrm{OH}: \mathrm{CH}_{3} \mathrm{COOH}: \mathrm{H}_{2} \mathrm{O} \quad(100: 60: 16: 8)$, or $\mathrm{CHCl}_{8}: \mathrm{CH}_{3} \mathrm{OH}: \mathrm{H}_{2} \mathrm{O}(65: 25: 4)$.

Adenylate cyclase assay. Adenylate cyclase was assayed by the method of Krishna, Weiss, and Brodie (13). The fractions for assay containing $0.025-0.05 \mathrm{mg}$ protein in a total volume of $0.06 \mathrm{ml}$ were incubated at $37^{\circ} \mathrm{C}$ for $5 \mathrm{~min}$

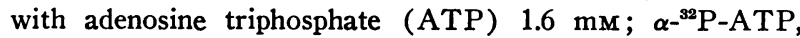
2.5-3.5 $\times 10^{6} \mathrm{cpm}$; theophylline, $8 \mathrm{mM} ; \mathrm{MgCl}_{2}, 2 \mathrm{mM}$; Tris$\mathrm{HCl}, 21 \mathrm{~mm}, \mathrm{pH} 7.7$; and human serum albumin, $0.8 \mathrm{mg} / \mathrm{ml}$. Phosphatidylserine dispersed in Tris- $\mathrm{HCl}, 10 \mathrm{~mm}, \mathrm{pH} 7.7$, and histamine were added to the enzyme at $1^{\circ} \mathrm{C}$ at final concentrations stated in the text. The incubations were initiated by adding the enzyme-phosphatidylserine-histamine mixture at $1^{\circ} \mathrm{C}$ to the other components which were at $23^{\circ} \mathrm{C}$. After $5 \mathrm{~min}$ the incubations were stopped and the ${ }^{32} \mathrm{P}$-cyclic $3^{\prime}, 5^{\prime}$-adenosine monophosphate (AMP) accumulated was determined as previously described (9). Protein was measured by the method of Lowry, Rosebrough, Farr, and Randall, using bovine serum albumin as a standard (14).

Material. Chromatographically pure phosphatidylserine was prepared from bovine brain by Dr. S. Ramachandran, Applied Science Laboratories, State College, $\mathrm{Pa}$. Histamine phosphate and crystalline glucagon were gifts from Eli Lilly \& Co., Indianapolis, Ind.; diphenhydramine hydrochloride (Benadryl) was from Parke, Davis \& Co., Detroit, Mich. Lubrol-PX was a gift from I.C.I. America Inc., Stamford, Conn. Alpha-labeled ${ }^{32} \mathrm{P}-\mathrm{ATP}$ was from International Chemical and Nuclear Corp., Irvine, Calif.

\section{RESULTS}

Effect of phosphatidylserine on the histamine responsiveness of solubilized myocardial adenylate cyclase.

TABLE I

Effect of Phosphatidylserine on Restoring Histamine Activation of Solubilized Cat Myocardial Adenylate Cyclase

\begin{tabular}{|c|c|c|c|}
\hline \multirow[b]{2}{*}{ s } & \multicolumn{3}{|c|}{$\begin{array}{c}\text { Cyclic } 3^{\prime}, 5^{\prime} \text {-AMP accumulated } / 5 \mathrm{~min} \\
\text { per } \mathrm{mg} \text { protein }\end{array}$} \\
\hline & Control & $\begin{array}{c}\text { Histamine } \\
\left(8 \times 10^{-5} \mathrm{M}\right)\end{array}$ & $\begin{array}{c}P \\
\text { value }\end{array}$ \\
\hline & pmoles & pmoles & \\
\hline $\begin{array}{l}\text { Particulate enzyme } \\
\text { Solubilized enzyme }\end{array}$ & $200 \pm 25(12)^{*}$ & $475 \pm 30(12)$ & $<0.01$ \\
\hline $\begin{array}{l}\text { DEAE fraction } \\
\text { DEAE fraction plus } 8 \mu \mathrm{g}\end{array}$ & $469 \pm 27$ & $540 \pm 45(10)$ & NS $\ddagger$ \\
\hline phosphatidylserine* & $700 \pm 40(13)$ & $1450 \pm 45(15)$ & $<0.01$ \\
\hline
\end{tabular}

* The number of samples are shown in parentheses.

$\ddagger N S=$ not significant.

The phosphatidylserine: protein ratio was 1:3-6.

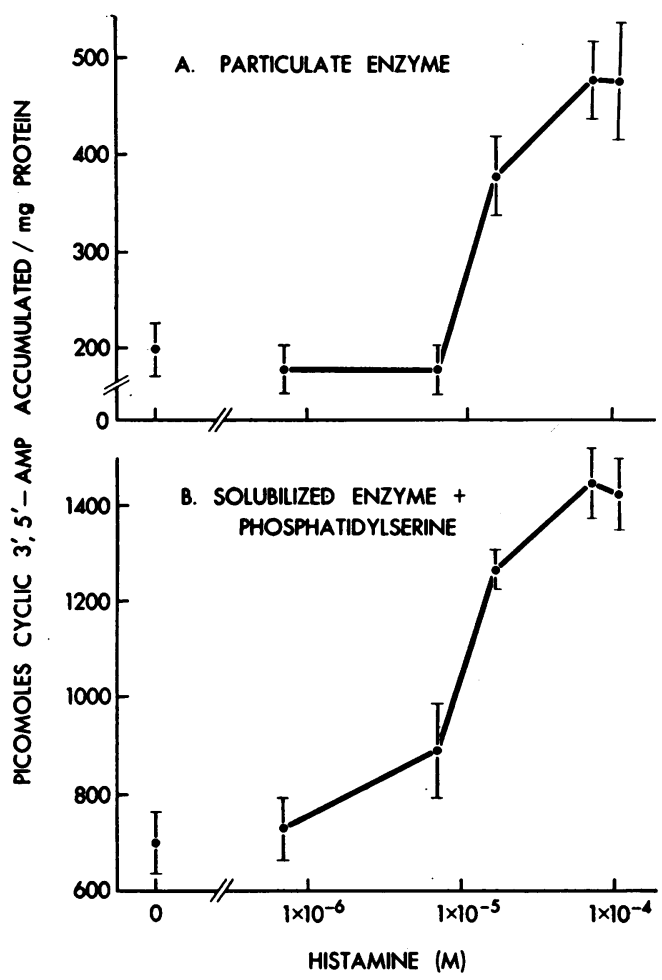

FIGURE 1 Effect of increasing concentrations of histamine on myocardial adenylate cyclase. Each value represents the mean \pm SE of 6-13 samples from three cats for both the particulate and solubilized myocardial adenylate cyclase preparations. Phosphatidylserine was present at $8 \mu \mathrm{g} /$ incubation and the phosphatidylserine: protein ratio was $1: 3-6$.

Histamine, $8 \times 10^{-5} \mathrm{M}$, maximally activates the particulate cat myocardial adenylate cyclase, producing approximately a $100 \%$ increase in cyclic $3^{\prime}, 5^{\prime}$-AMP accumulation (Table I). The solubilized adenylate cyclase was not activated by histamine; however, the addition of phosphatidylserine restored histamine responsiveness (Table I). Phosphatidylserine did not restore norepinephrine activation (12).

Histamine activates the particulate adenylate cyclase over the concentration range $2 \times 10^{-6} \mathrm{M}-8 \times 10^{-5} \mathrm{M}$, half-maximal activation of the enzyme occurring at approximately $2 \times 10^{-5}$ M (Fig. $1 \mathrm{~A}$ ). As shown in Fig. $1 \mathrm{~B}$, histamine activates the solubilized adenylate cyclase, in the presence of added phosphatidylserine, over a similar concentration range. Furthermore, halfmaximal activation occurred at a concentration of histamine, $2 \times 10^{-5} \mathrm{M}$, identical with that observed for the particulate enzyme.

Effect of diphenhydramine on the histamine-mediated activation of adenylate cyclase. Diphenhydramine hydrochloride at $8 \times 10^{-5} \mathrm{M}$ abolished the activation of the solubilized adenylate cyclase produced by histamine, $8 \times 10^{-5}$ м (Fig. 2). Similar findings have been re- 


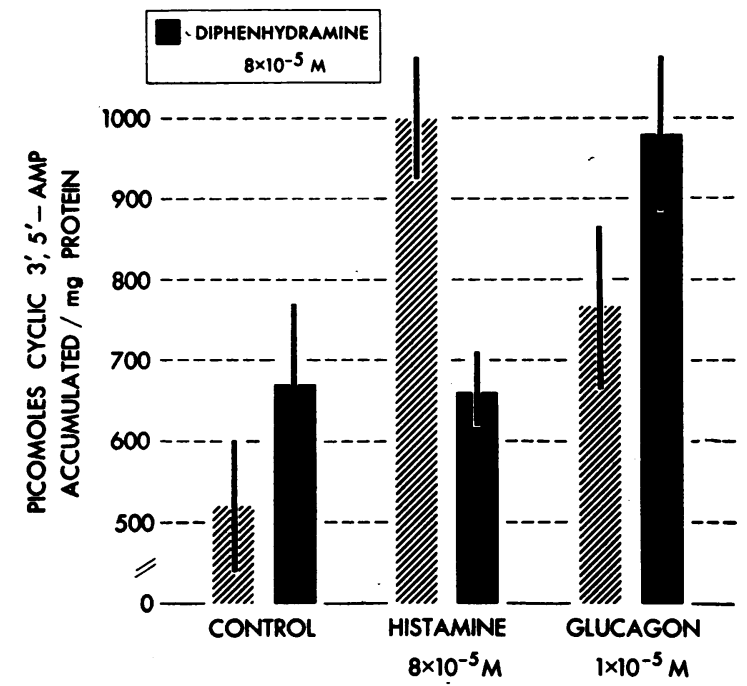

Figure 2 Effect of diphenhydramine on the histaminemediated activation of solubilized adenylate cyclase in the presence of phosphatidylserine. Each value represents the mean \pm SE of 6-8 samples from two cats. Phosphatidylserine was present at $8 \mu \mathrm{g} /$ incubation and the phosphatidylserine: protein ratio was $1: 3-4$.

ported for the particulate enzyme (4). Glucagon responsiveness' of the solubilized myocardial adenylate cyclase is also restored by the phosphatidylserine (12). However, diphenhydramine did not abolish the activation of the solubilized adenylate cyclase by glucagon (Fig. 2).

Effect of combined maximal concentrations of glucagon and histamine. Combined maximal concentrations of glucagon and histamine did not produce increases in cyclic $3^{\prime}, 5^{\prime}$-AMP accumulation above that observed with the individual hormones (Table II).

Effect of increasing concentrations of phosphatidylserine. Fig. 3 shows that phosphatidylserine effectively

TABLE II

Effect of Combined Maximal Doses of Histamine and Glucagon

\begin{tabular}{lc}
\hline & $\begin{array}{c}\text { Cyclic } \\
3^{\prime}, 5^{\prime}-\mathrm{AMP} \\
\text { accumulated/ } \\
5 \text { min per } \mathrm{mg} \\
\text { protein* }\end{array}$ \\
\hline & pmoles \\
Control $\neq$ & $760 \pm 100$ \\
Histamine $\left(8 \times 10^{-5} \mathrm{M}\right)$ & $1720 \pm 150$ \\
Glucagon $\left(1 \times 10^{-5} \mathrm{M}\right)$ & $1240 \pm 60$ \\
Histamine plus glucagon & $1560 \pm 120$
\end{tabular}

* Each value represents the mean $\pm \mathrm{SE}$ of three samples. $\ddagger$ Phosphatidylserine was present at $8 \mu \mathrm{g} /$ incubation and the phosphatidylserine: protein ratio was 1:5. restored histamine responsiveness over the concentration range 2-8 $\mu \mathrm{g} /$ incubation $(32-128 \mu \mathrm{g} / \mathrm{ml})$.

Effect of other phospholipids. Two other phospholipids tested, phosphatidylethanolamine and phosphatidylinositol, did not restore histamine responsiveness (Fig. 4).

\section{DISCUSSION}

A substantial amount of evidence has accumulated demonstrating that membrane lipids are vital to hormonesensitive adenylate cyclase systems. Sutherland, Rall, and Menon solubilized adenylate cyclase from a number of tissues including brain, heart, skeletal muscle, and liver and noted a diminished to absent hormone responsiveness of the enzyme (15). They suggested that adenylate cyclase may be a lipoprotein and that its in vivo activity may be dependent on the lipid-protein complex. Recently, Rodbell, Birnbaumer, Pohl, and Krans demonstrated that glucagon binding to isolated liver membranes and the subsequent activation of the adenylate cyclase in these membranes could be abolished by treatment of the membranes with either the nonionic detergent, digitonin, or phospholipase A $(16,17)$. They extended these findings and showed that the addition of pure phosphatidylserine and to a lesser extent, phosphatidylcholine and phosphatidylethanolamine partially restored glucagon binding and activation of adenylate cyclase (18). We have reported that the addition of pure phosphatidylserine restored the glucagon-responsiveness of a solubilized preparation of cat myocardial adenylate cyclase. Furthermore, half-maximal activation of the enzyme occurred at a concentration of glucagon almost identical with that reported for the particulate (membrane-bound) enzyme (12).

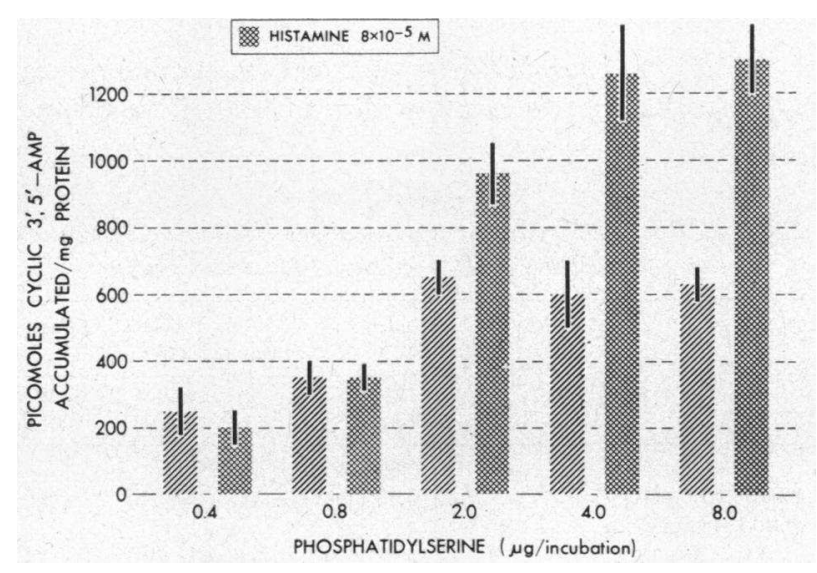

FIGURE 3 Effect of varying concentrations of phosphatidylserine on restoring the histamine-mediated activation of adenylate cyclase. Each value represents the mean $\pm_{S E}$ of three samples. The ratio of phosphatidylserine to protein ranged from $1: 100$ to $1: 5$. 
The data presented in this report demonstrate that phosphatidylserine also restored histamine responsiveness to this same preparation of solubilized cat myocardial adenylate cyclase freed of detergent by DEAE-cellulose chromatography. The values for maximal per cent increase in cyclic $3^{\prime}, 5^{\prime}$-AMP accumulation (100\%) and concentration of histamine which produced half-maximal activation of the enzyme $\left(2 \times 10^{-5} \mathrm{M}\right)$ were virtually identical with those observed for the particulate enzyme.

The activation of the particulate adenylate cyclase by histamine is abolished by the antihistamine diphenhydramine (4). Similarly, the activation of the solubilized enzyme by histamine in the presence of phosphatidylserine was also abolished by an equimolar concentration of diphenhydramine providing evidence that this reconstituted system responded in a similar manner to the membrane-bound adenylate cyclase system. Further receptor specificity was demonstrated when diphenhydramine specifically abolished the response to histamine but not the response to glucagon restored by the presence of phosphatidylserine.

Phosphatidylserine did not restore norepinephrine responsiveness. Norepinephrine activation of the adenylate cyclase occurs by a separate and distinct receptor mechanis, the beta adrenergic receptor. We have recently found that another phospholipid, phosphatidylinositol, restored norepinephrine responsiveness, but not that of glucagon or histamine (19). The selective and specific requirement of phosphatidylinositol for catecholamine activation of myocardial adenylate cyclase and phosphatidylserine for histamine and glucagon activation parallels the known physiologic distinction between the discrete beta adrenergic receptor and other hormone receptor systems for adenylate cyclase activation.

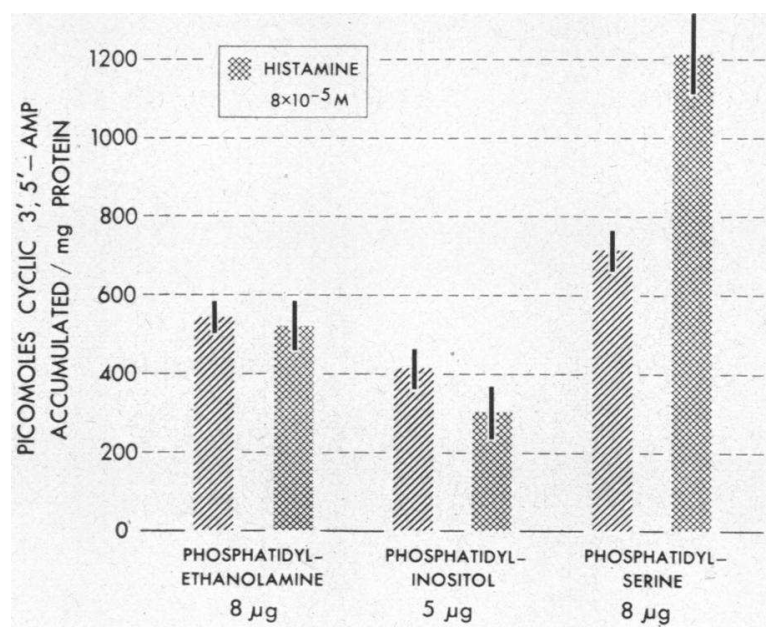

FIGURE 4 Effect of other phospholipids on restoring the histamine-activation of adenylate cyclase. Each value represents the mean $\pm \mathrm{SE}$ of three samples.
These in vitro studies provide an insight into the components which compose the cardiac histamine receptor in vivo. However, it should be noted that since the enzyme fraction in this preparation is impure, it is not possible to conclude whether any other factor is present and a necessary component of the histamine receptor in addition to phosphatidylserine and adenylate cyclase. Furthermore, the exact mechanism of action of the lipid is unclear. Phosphatidylserine may induce the specific conformational change in the adenylate cyclase molecule necessary for histamine binding and activation of the enzyme.

Rodbell, Birnbaumer, and Pohl consider the membranebound adenylate cyclase to be a three-component system (20). The total unit consists of a regulatory site (discriminator), a catalytic site (amplifier), and an intermediate coupler (transducer). The regulatory site, which faces the external surface of the membrane, discriminates between hormones and serves as the binding site of hormone to target membrane. The catalytic site faces the interior surface of the membrane, has access to ATP, the substrate for the enzyme, and is ultimately responsible for generating the cyclic $3^{\prime}, 5^{\prime}$-AMP. An intermediate unit or coupler serves to transmit a signal from the regulatory site to the catalytic site. The catalytic site can be directly activated by sodium fluoride (18). Moreover, activation of the catalytic site appears to be independent of lipid since fluoride activation of the solubilized adenylate cyclase is unimpaired whereas hormone activation is absent $(5,15,16)$. Therefore, the lipid probably interacts either with the regulatory site or coupler. Rodbell, Birnbaumer, and Pohl postulated that the lipid is necesary for the coupler. This hypothesis could be substantiated if binding of a hormone, such as histamine, to the solubilized adenylate cyclase could be demonstrated in the absence of added lipid. Thus, the coupler would be implicated as the lipid-requiring site. Studies to further elucidate this problem are currently under investigation.

\section{ACKNOWLEDGMENTS}

The authors are grateful to Mrs. Eva Ruiz and Mrs. Antoinette Schenk for their excellent technical assistance.

This investigation was supported in part by National Institutes of Health grant 1-R01 HE13715-01, Florida Heart Association grant 71AG20, and the New York University School of Medicine Honors Program.

\section{REFERENCES}

1. Trendelenburg, U. 1960. The action of histamine and 5-hydroxy-tryptamine on isolated mammalian atria. $J$. Pharmacol. Exp. Ther. 130: 450.

2. Bartlet, A. L. 1963. The action of histamine on the isolated heart. Brit. J. Pharmacol. Chemother. 21: 450.

3. Poch, G. and W. R. Kukovetz. 1967. Drug-induced release and pharmacodynamic effects of histamine in the guinea-pig heart. J. Pharmacol. Exp. Ther. 156: 522. 
4. Klein, I., and G. S. Levey. 1971. Activation of myocardial adenyl cyclase by histamine in guinea pig, cat and human heart. J. Clin. Invest. 50: 1012.

5. Levey, G. S. 1970. Solubilization of myocardial adenyl cyclase. Biochem. Biophys. Res. Commun. 38: 86.

6. Levey, G. S. 1971. Solubilization of myocardial adenyl cyclase: loss of hormone-responsiveness and activation by phospholipids. Ann. N. Y. Acad. Sci. 185: 449.

7. Murad, F., Y.-M. Chi, T. W. Rall, and E. W. Sutherland. 1962. Adenyl cyclase. III. The effect of catecholamines and choline esters on the formation of adenosine $3^{\prime}, 5^{\prime}$-phosphate by preparations from cardiac muscle and liver. J. Biol. Chem. 237 : 1233.

8. Levey, G. S., and S. E. Epstein. 1969. Activation of adenyl cyclase by glucagon in cat and human heart. Circ. Res. $24: 151$

9. Levey, G. S., and S. E. Epstein. 1969. Myocardial adenyl cyclase: activation by thyroid hormones and evidence for two adenyl cyclase systems. J. Clin. Invest. 48 : 1663.

10. Waud, D. R. 1968. Pharmacological receptors. Pharmacol. Rev. 20 : 49.

11. Ehrenpreis, S., J. H. Fleish, and T. W. Mittag. 1969. Approaches to the molecular nature of pharmacological receptors. Pharmacol. Rev. 21: 131.

12. Levey, G. S. 1971. Restoration of glucagon responsiveness of solubilized myocardial adenyl cyclase by phosphatidylserine. Biochem. Biophys. Res. Commun. 43: 108.

13. Krishna, G., B. Weiss, and B. B. Brodie. 1968. A simple, sensitive method for the assay of adenyl cyclase. J. Pharmacol. Exp. Ther. 163: 379.
14. Lowry, O. H., M. T. Rosebrough, A. L. Farr, and R. J. Randall. 1951. Protein measurement with the folin phenol reagent. J. Biol. Chem. 193: 265.

15. Sutherland, E. W., T. W. Rall, and T. Menon. 1962. Adenyl cyclase. I. Distribution, preparation, and properties. J. Biol. Chem. 237: 1220.

16. Birnbaumer, L., S. L. Pohl, and M. Rodbell. 1971. The glucagon-sensitive adenyl cyclase system in plasma membranes of rat liver. II. Comparison between glucagon- and fluoride-stimulated activities. J. Biol. Chem. 246: 1857.

17. Rodbell, M., H. M. J. Krans, S. L. Pohl, and L. Birnbaumer. 1971. The glucagon-sensitive adenyl cyclase system in plasma membranes of rat liver. III. Binding of glucagon: method of assay and specificity. J. Biol. Chem. 246: 1861 .

18. Pohl, S. L., H. M. J. Krans, V. Kozyreff, L. Birnbaumer, and M. Rodbell. 1971. The glucagon-sensitive adenyl cyclase system in plasma membranes of rat liver. VI. Evidence for a role of membrane lipids. J. Biol. Chem. 246: 4447.

19. Levey, G. S. 1971. Restoration of norepinephrine-responsiveness of solubilized myocardial adenylate cyclase by phosphatidylinositol. J. Biol. Chem. 246: 7405.

20. Rodbell, M., L. Birnbaumer, and S. L. Pohl. 1971. Hormones, receptors, and adenyl cyclase activity in mammalian cells. In The Role of Adenyl Cyclase and Cyclic $3^{\prime}, 5^{\prime}$-AMP in Biological Systems. T. W. Rall, M. Rodbell, and P. G. Condliffe, editors. National Institutes of Health, Bethesda, Md. 